\title{
Desain Pembelajaran Bilangan Melalui Permainan Sut-Sut Menggunakan Pendekatan PMRI Di Kelas III Sekolah Dasar
}

\author{
(Design Of Learning Numbers Through Game-Sut Sut Using PMRI Approach In Class III \\ Elementary School)
}

\author{
Nini Ratna Sari ${ }^{1}$, Mustamin Anggo ${ }^{2}$, Kodirun $^{2}$ \\ ${ }^{1}$ Guru SD Negeri 21 Kendari Barat, Alumnus Prodi Pendidikan Matematika PPs Universitas Halu Oleo \\ ${ }^{2}$ Dosen Pendidikan Matematika FKIP dan PPs Universitas Halu Oleo; Co-author: \\ mustaminanggo@gmail.com
}

\begin{abstract}
Abstrak: Penelitian ini bertujuan: (1) Untuk mengetahui desain pembelajaran bilangan melalui permainan sut-sut menggunakan pendekatan pendidikan matematika realistik indonesia dapat digunakan siswa untuk memperoleh pengetahuan awal bilangan dan konsep dasar bilangan di kelas III sekolah dasar, (2) Menghasilkan desain pembelajaran bilangan melalui permainan sut-sut menggunakan pendekatan PMRI dapat mengembangkan pemahaman bilangan siswa tentang konsep bilangan melalui aktivitas informal ke formal di kelas III sekolah dasar dan (3) Untuk mengetahui desain pembelajaran bilangan melalui permainan sut-sut menggunakan pendekatan PMRI dapat meningkatkan hasil belajar siswa di kelas III sekolah dasar. Penelitian ini merupakan penelitian yang dilaksanakan dalam 3 tahap yakni perecanaan desain, percobaan desain, dan analisis retrospektip. Subjek yang dilibatkan dalam penelitian ini adalah guru dan siswa kelas III MI ICI dan SDN 21 kendari barat yang mengajarkan di kelas tersebut.. Berdasarkan bukti yang diperoleh, temuan di lapangan menunjukkan bahwa bermain sut-sut dapat digunakan siswa sebagai titik awal pembelajaran yang mendukung mereka untuk mendapatkan pengetahuan awal dan konsep dasar bilangan yang diharapkan. Melalui masalah yang dikembangkan dari konteks bermain sut-sut, perkembangan pemahaman bilangan mereka ditujukkan dengan beraneka ragam strategi yang tepat dalam menyelesaikan masalah, dan kemampuan berpikir kritis ketika mereka mengkomunikasikan ide dan pertanyaan dalam diskusi.
\end{abstract}

Kata kunci: Desain Pembelajaran, permainan sut-sut, bermain rumah, pendekatan PMRI.

\begin{abstract}
This study aimed to: (1) find out the design of learning numbers through sut-sut game by using Indonesian realistic mathematics education which could be used by students to obtain basic knowledge and concept of numbers at grade III of elementary school, (2) to produce a design of learning numbers through sut-sut game by using Indonesian realistic mathematics education to develop students' understanding of numerical concepts through formal activities at grade III of elementary school; (3) to find out the design of learning numbers through sut-sut game by using Indonesian realistic mathematics education to improve students' results of learning grade III of elementary school. The study was conducted in three stages, namely planning of design, experimenting of the design, and a retrospective analysis. Subjects of the study were teacher and students of grade III of MI ICI and SDN 21 of West Kendari which applied the method. Based on the evidence found in the field, it was revealed that the sut-sut game could be used by students as a starting point of their learning which could support the students to get initial knowledge of and concepts of numbers that were expected. Through the problems that were developed from the context of sut-sut game, the development of the students' understanding of numbers was indicated by the use of a variety of correct strategies for solving problems, and their critical thinking ability when communicating their ideas and asking questions during discussions.
\end{abstract}

Keywords: Learning Design, Sut-Sut Game, House Game, Indonesian Realistic Mathematics Education

\section{PENDAHULUAN}

Pendidikan merupakan hal yang paling pokok dalam kehidupan manusia. Pendidikan yang baik dapat diperoleh dengan menggunakan metode

pembelajaran yang benar sehingga maksud dan tujuan dari pendidikan itu sendiri dapat dicapai. Proses pembelajaran Desain Pembelajaran Bilangan Melalui Permainan Sut-Sut Menggunaan Pendekatan PMRI Di Kelas III Sekolah Dasar (Nini Ratna Sari, Mustamin, Kodirun) 
keseluruhan dan guru sebagai pemegang peranan utama, dimana serangkaian perbuatan guru dan siswa atas dasar hubungan timbal balik yang berlangsung dalam situasi edukatif untuk mencapai tujuan tertentu. Interaksi hubungan timbal balik antara guru dengan siswa merupakan syarat utama bagi berlangsungnya proses belajar mengajar.

Kurikulum tingkat satuan pendidikan (KTSP) dan kurikulum 2013 merupakan acuan pendidikan di Kendari, pada tingkat sekolah dasar menekankan 3 aspek diantaranya: bilangan, geometri dan pengukuran, dan pengolahan data (statistik). Pembelajaran bilangan tingkat sekolah dasar menjadi penting untuk pembelajaran topik lainnya (Freudenthal, 1973; NCTM, 2000), pembelajaran bilangan cenderung untuk membentuk pemahaman tentang notasi, simbol, dan bentuk lainnya yang mewakili sehingga dapat mendukung pemikiran dan pemahaman anak untuk menyelesaikan masalah mereka (NCTM, 2000). Karena itu, pembelajaran bilangan menjadi salah satu pengetahuan prasyarat untuk pembelajaran topik lainnya dalam pembelajaran matematika.

Anak-anak Kendari memiliki kesenangan dengan bermain. Contoh, anak sekolah dasar daerah Sulawesi Tenggara menggemari permainan Sut-sut, kemudian permainan tersebut dimainkan di waktu istirahat sekolah, (dikenal dengan keluarmain). Adapun proses menyelesaikan permainan ini dengan sut yang membutuhkan dua pemain (siswa) atau lebih. Pertama siswa membuat rumah kemudian siswa saling sut kemudian menuliskan tanda garis diagonal yang saling bersilangan hingga memenuhi satu kotak, diteruskan memenuhi seluruh kotak pada satu rumah tersebut. Lalu pemain tersebut berhak untuk berpindah dengan membangun satu rumah selanjutnya, yang dikenal dengan rumah baru, sehingga perubahan setiap kali membagun rumah yang terjadi adalah adanya urutan bilangan
$1,2,3, \ldots$, dan seterusnya. Uniknya, permainan ini juga dimainkan di daerah lain meskipun namanya berbeda.

Permainan sut-sut dan gambar "rumah" menjadi bagian yang menarik bagi pemain (siswa) untuk berkompetisi satu sama lain sebagai pemenang, dan untuk materi pembelajaran dapat dikaitkan dengan penggunaan bilangan di dalamnya. Wijaya (2008) telah melakukan penelitian dengan merancang pembelajaran yang melibatkan permainan gundu dan benthik (patok lele) untuk konsep pengukuran linear, hasilnya diungkapkan bahwa siswa memahami ide transitivitas dan perbandingan tak langsung.

Pendidikan Matematika Realistik Indonesia (PMRI) adalah satu pendekatan pembelajaran yang diterapkan di Kendari yang juga dikenal Realistic Mathematics Education untuk di luar Kendari. Berdasarkan hasil observasi yang telah dilakukan, pertanyaan Treffers (Streefland, 1991) menjadi menarik untuk dikaji tentang pengajaran berhitung accoustic, synchronous, dan resultative. Dengan asumsi bahwa meskipun mereka dapat berhitung banyak bilangan dari 1 digit lalu 2 digit, tidak menjamin mereka benar memahami konsep dasar berhitung synchronous dan resultative. Masalah seperti ini yang banyak terjadi pada siswa di Kendari.

Permainan dan pengetahuan bilangan siswa yang dimiliki adalah salah satu alternatif yang menarik. Masalah tersebut membutuhkan penyelesaian yang tepat terutama untuk siswa, Siswa bermain dan siswa memiliki pengetahuan bilangan, bahkan bersamaan siswa belajar dengan permainan akan mengoptimalkan potensi pemahaman bilangannya. Melalui suatu penelitian desain, bermain Sut-sut sebagai konteks akan diterapkan sebagai titik awal (starting point) dalam pembelajaran bilangan siswa. Terpadu dengan pendekatan PMRI akan diterapkan di Sekolah Dasar Negeri (SDN) 21 Kendari Barat dan Madrasah Ibtidayah Insan 
Cendikia Islamiah (MI ICI), melalui percobaan desain untuk mengetahui sejauh mana peran konteks bermain Sut-sut dalam mendukung pembelajaran bilangan siswa. Selain itu, bagaimana

\section{METODE PENELITIAN}

Tujuan utama penelitian ini adalah untuk menelusuri bagaimana permainan sut-sut di Kendari dapat digunakan untuk mengembangkan pemahaman bilangan siswa dan mencapai tujuan pembelajaran matematika berkaitan dengan bilangan.Menurut Gravemeijer \& Cobb dalam Gravemeijer \& Eerde (2009) penelitian desain menenkankan pada penyesuaian pengembangan subjek dan topik untuk teori instruksi khusus dalam pendidikan matematika. Wang \& Hannafin dalam Simonson (2006) mendefinisikan penelitian desain sebagai metode yang sistematik ditujukan untuk meningkatkan pelaksanaan pengajaran melalui analisis berulang, desain berulang, dan implementasi, mengacu pada kolaborasi antara peneliti dan praktisi dengan situasi kehidupan sehari-hari. Jenis penelitian desain ini adalah penelitian kualitatif,

\section{HASIL PENELITIAN}

Percobaan pengajaran I yang terbagi atas 4 aktivitas merupakan kegiatan pembelajaran yang berbasis pengalaman bermain sut-sut. Siswa belajar sambil bermain sut-sut, kemudian hasil dari bermain tersebut dikembangkan melalui berbagai masalah berbeda tingkatan. Seperti yang diharapkan, garis bersilangan berpotensi sebagai angka dan nomor rumah menjadi bilangan acuan, gabungan dari keduanya menjadi bilangan. Konsep seperti ini yang dapat ditemukan siswa, meskipun mereka tidak menyadari hal tersebut. Oleh karena itu, pemahaman bilangan yang dimaksudkan dalam hal ini perkembangan bilangan siswa mulai dari aktivitas main (informal) hingga aktivitas formal.

sehingga analisis data dilakukan dengan prinsip penelitian kualitatif. Untuk suatu penelitian yang memperhatikan keabsahan data dan trasferabilitas.

Dalam desain pendahuluan, ide awal yang diimplementasikan merupakan inspirasi dari kajian literatur sebelum merancang aktivitas pembelajaran. Ada 2 hal yang dilakukan, yaitu: (a) Kajian literatur, penelitian ini dimulai dengan mengkaji literatur mengenai membilang dan pemahaman bilangan, Pendidikan Matematika Realistik Indonesia, dan penelitian desain sebagai basis untuk merumuskan dugaan awal dalam pembelajaran membilang; (b) Mendesain Rencana Lintasan Belajar, pada fase ini, dikembangkan serangkaian aktivitas pembelajaran memuat dugaan strategi dan penalaran siswa

adalah kemampuan mengenali bilangan acuan dan bilangan, dan mengetahui besaran dan operasi hitung terhadap bilangan tersebut. Ketika masalah bilangan berbasis rumah diberikan diawali dari rumah 1-3, 1-4, 1-10, dan 1-80 mereka dapat menunjukkan berbagai strategi dalam penyelesaian. Sasaran utama penelitian ini adalah siswa mampu melakukan operasi hitung penjumlahan bilangan 3 digit dan mengaitkannya dengan perkalian yang hasilnya berupa bilangan 3 digit 
Tabel 1. Strategi berhitung yang digunakan siswa dengan masalah lanjutan pada percobaan pengajaran I

\begin{tabular}{|c|c|c|c|c|}
\hline \multirow[b]{2}{*}{ No. } & \multirow[b]{2}{*}{ Pilihan Strategi } & \multicolumn{3}{|c|}{ Masalah } \\
\hline & & $\begin{array}{c}\text { Konteks } \\
\text { kambang } \\
\text { Iwak }\end{array}$ & $\begin{array}{c}\text { Konteks } \\
\text { tapak } \\
\text { lintasan } \\
\text { batu }\end{array}$ & $\begin{array}{l}\text { Kotak } \\
\text { buku }\end{array}$ \\
\hline 1 & pola/Memberikan & $12 / 14$ & $12 / 14$ & - \\
\hline 2 & Penjumlahan ke samping & $9 / 14$ & $10 / 14$ & $11 / 14$ \\
\hline 3 & Penjumlahan bersusun ke bawah & $9 / 14$ & $4 / 14$ & $5 / 14$ \\
\hline 4 & $\begin{array}{l}\text { Penjumlahan berlapis terpadu pola } \\
\text { garis bilangan }\end{array}$ & $5 / 14$ & $2 / 14$ & $6 / 14$ \\
\hline 5 & Perkalian & $1 / 14$ & $2 / 14$ & $6 / 14$ \\
\hline
\end{tabular}

Berdasarkan tabel 1, siswa menunjukkan perkembangan pemahaman bilangan melalui 5 pilihan strategi yang digunakan. Pilihan strategi yang paling banyak digunakan adalah penjumlahan ke samping, kemudian penjumlahan berlapis terpadu pola garis bilangan. Dari 5 pilihan strategi hanya 4 yang lebih banyak digunakan siswa untuk menyelesaikan masalah dalam aktivitas III dan IV. Perubahan kuantitas perbandingan untuk setiap masalah menunjukkan perkembangan pemahaman bilangan siswa berdasarkan masalah yang diberikan. Kemudian hampir seluruh siswa dapat memberikan jawaban baik dan benar untuk masalah aktivitas IV, hal ini menunjukkan bahwa siswa sepertinya sudah memahami maksud dari permasalahan dan strategi yang tepat untuk menyelesaikannya.

Data hasil belajar siswa di peroleh dari hasil tes tertulis siswa dan dianalisis untuk mengetahui meningkat tidaknya hasil belajar siswa dalam desain pembelajaran bilangan melalui permainan sut-sut setelah penelitian ini dilakukan. Dari data pelaksanaan uji tes pada siswa kelas III/A MI ICI menunjukkan bahwa hasil belajar siswa dengan desain pembelajaran bilangan melalui permainan sut-sut cukup baik. Dari hasil tes diketahui bahwa siswa yang tuntas dari KKM sebanyak 21 siswa $(84 \%)$ dari 7 siswa dengan nilai tertinggi: 100 dan nilai terendah sebanyak 4 siswa (16\%) dengan nilai rata-rata 81,4 .

Dari hasil analisis dapat diketahui bahwa sebagian besarsiswa, telah melakukan apa yang seharusnya mereka lakukan dalam suatu proses pembelajaran, yaitu dengan melakukan aktivitas siswa dalam merespon petunjuk/pertanyaan guru dan aktivitas siswa dalam kegiatan diskusi kelompok dan diskusi kelas. Hasil observasi tersebut disajikan pada Tabel 2.

Tabel 2. Data Hasil Observasi Aktvitas Siswa pada Percobaan I

\begin{tabular}{cccccccc}
\hline Percobaan & $\mathbf{1}$ & $\mathbf{2}$ & $\mathbf{3}$ & $\mathbf{4}$ & $\mathbf{5}$ & $\mathbf{6}$ & Rata-rata(\%) \\
\hline Keaktifan & 61,67 & 70,59 & 89,71 & 94,12 & 97,06 & 98,53 & 85,30 \\
Siswa (\%) & & & & & & & \\
\hline
\end{tabular}

Dari Tabel 2 menunjukkan bahwa aktivitas siswa telah mencapai rata-rata $85,30 \%$, ini berarti secara keseluruhan percobaan pembelajaran, siswa telah masuk dalam kategori sangat aktif dalam proses pembelajaran bilangan. Pada percobaan pertama dalam pembelajaran bilangan, aktivitas siswa masih belum mencapai maksimal dalam proses pembelajaran, hal tersebut terlihat sesuai 
hasil pantauan observer, keaktifan siswa hanya mencapai $61,67 \%$. Sesuai hasil observasi, yang masing kurang baik adalah ketika siswa diminta untuk menjelaskan dengan bahasa yang tepat/akurat apa yang telah diamatinya dalam Lambar Kegiatan Siswa (LKS) yang telah dibagikan. Siswa juga masih mengalami kesulitan bekerja dalam kelompoknya, namun bisa teratasi ketika guru atau peneliti memberi arahan tentang prosedur yang siswa harus mulai dikerjakan. Selanjutnya siswa juga masih kesulitan dalam menjelaskan hasil kerja dalam kelompoknya, dan siswa masih kurang dalam membuat rangkuman konsep yang telah dipelajari dengan mengungkapkan secara lisan atau tertulis.

Pada percobaan pertama siswa sudah terlihat adanya perubahan dari kesulitankesulitan yang dialami pada percobaan pertama, sudah bisa mulai mengatasinya. Hal ini terlihat sesuai hasil pantauan observer telah mencatat keaktifan siswa mencapai $76,59 \%$. Selanjutnya pada percobaan ketiga keaktifan siswa semakin bertambah sehingga observer mencatat keaktifan siswa mencapai $89,71 \%$. Demikian seterusnya hingga percobaan keenam keaktifan siswa mencapai 98,53\%.

Hasil refleksi penelitian bersama guru kolaborator setelah pelaksanaan disimpulkan: (1) kegiatan percobaan I berjalan cukup baik, (2) siswa yang melaksanakan percobaan I sangat antusias
(3) LKS yang diberikan guru kepada siswa mampu menuntun siswa dalam bereksperimen dan mengenferensi hasil percobaan I yang ditemukan (4) nilai ratarata siswa mencapai 81,4 dari 25 siswa yang mengikuti pembelajaran.

Berdasarkan hasil refleksi percobaan I sudah cukup baik tetap ada beberapa hal yang perlu diperbaiki. Karena peningkatan nilai anak juga sangat dipengaruhi banyaknya tindakan perbaikan yang dilakukan oleh guru, semakin banyak tindakan perbaikan oleh guru pada kegiatan mengajar maupun kegiatan siswa sehingga dapat meningkatkan hasil belajar siswa.

Pengembangan masalah dengan melakukan modifikasi seperti yang dilakukan dalam percobaan pengajaran II. Masalah diberikan dengan menambahkan kata-kata tertentu, ternyata ditanggapi siswa dengan adanya pelibatan strategi lain untuk menyelesaikan masalah. Masalah yang telah diberikan pada percobaan pengajaran I dimodifikasi dengan menambahkan kata "yang dibutuhkan", “yang harus ditempuh",dan "yang diperlukan. Selanjutnya untuk pengembangan masalah yang berkaitan dengan kehidupan sehari-hari. Berdasarkan masalah yang diberikan dalam aktivitas II dan III, perhatikan tabel berikut.

Tabel 3. Strategi berhitung yang digunakan siswa untuk masalah pada percobaan pengajaran II

\begin{tabular}{clcc}
\hline & \multicolumn{1}{c}{ Pilihan Strategi } & \multicolumn{2}{c}{ Masalah } \\
No. & & $\begin{array}{c}\text { Konteks } \\
\text { kambang }\end{array}$ & Kotak buku \\
\hline 1. & Membuat pola & 2 & - \\
2. & Penjumlahan kesamping & 7 & $6 / 13$ \\
3. & Penjumlahan bersusun kebawah & 9 & $9 / 13$ \\
4. & Penjumlahan berlapis terpadu pola garis bilangan & 1 & $1 / 13$ \\
5. & Perkalian & 1 & $2 / 13$ \\
6. & Pengurangan kesamping & 2 & $1 / 13$ \\
7. & Pengurangan bersusun kebawah & 6 & $1 / 13$ \\
8. & Penjumlahan dilanjutkan pengurangan & 1 & $1 / 13$ \\
9. & Perkalian dilanjutkan pengurangan & - & - \\
\hline
\end{tabular}

Desain Pembelajaran Bilangan Melalui Permainan Sut-Sut Menggunaan Pendekatan PMRI Di Kelas III Sekolah Dasar (Nini Ratna Sari, Mustamin, Kodirun) 

Berdasarkan tabel 3, perkembangan pemahaman siswa yang diberikan masalah aktivitas II dan III berbeda dengan masalah berbasis konteks bermain sut-sut. Dari dua masalah aktivitas II dan III, pilihan strategi yang muncul dari kedua aktivitas tersebut adalah pengurangan ke samping. Sesuai dengan dugaan, masalah aktivitas II dan III merupakan jenis masalah yang dapat diselesaikan dengan strategi pengurangan. Namun, strategi penjumlahan juga memungkinkan bergantung dari pendekatan pemahaman siswa tersebut terhadap konteks.

Dari data pelaksanaan uji tes pada siswa kelas III/A SDN 21 kendari barat menunjukkan bahwa hasil belajar siswa dengan desain pembelajaran bilangan melalui permainan sut-sut mengalami peningkatan dari uji tes pertama. Dari hasil tes diketahui bahwa siswa yang tuntas dari KKM sebanyak 24 siswa $(88,89 \%)$ dimana 12 siswa dengan nilai tertinggi: 100 dan nilai terendah sebanyak 3 siswa $(11,11 \%)$ dengan nilai rata-rata 87,78 .

Dari hasil analisis dapat diketahui bahwa sebagian besar siswa, telah melakukan apa yang seharusnya mereka lakukan dalam suatu proses pembelajaran, yaitu dengan melakukan aktivitas siswa dalam merespon petunjuk/pertanyaan guru dan aktivitas siswa dalam kegiatan diskusi kelompok dan diskusi kelas. Hasil observasi tersebut disajikan pada Tabel 4.

Tabel 4. Data Hasil Observasi Aktvitas Siswa pada Percobaan II
\begin{tabular}{cccccc}
\hline Percobaan & $\mathbf{1}$ & $\mathbf{2}$ & $\mathbf{3}$ & $\mathbf{4}$ & Rata-rata(\%) \\
\hline Keaktifan & 70,67 & 89,71 & 97,06 & 98,53 & 95,30 \\
Siswa (\%) & & & & & \\
\hline
\end{tabular}

Dari Tabel 4 menunjukkan bahwa aktivitas siswa telah mencapai rata-rata $95,30 \%$, ini berarti secara keseluruhan percobaan pembelajaran, siswa telah masuk dalam kategori sangat aktif dalam proses pembelajaran bilangan.

Pada percobaan pertama dalam pembelajaran bilangan, aktivitas siswa sudah mencapai maksimal dalam proses pembelajaran, hal tersebut terlihat sesuai hasil pantauan observer, keaktifan siswa mencapai $70,67 \%$. Sesuai hasil observasi, yang sudah sangat baik ketika siswa diminta untuk menjelaskan dengan bahasa yang tepat/akurat apa yang telah diamatinya dalam Lambar Kegiatan Siswa (LKS) yang telah dibagikan. Siswa tidak lagi mengalami kesulitan bekerja dalam kelompoknya ketika guru atau peneliti memberi arahan tentang prosedur yang siswa harus mulai dikerjakan. Selanjutnya siswa tidak mengalami kesulitan dalam menjelaskan hasil kerja dalam kelompoknya, dan siswa sangat baik dalam membuat rangkuman konsep yang telah dipelajari dengan mengungkapkan secara lisan atau tertulis.

Pada percobaan kedua siswa sudah terlihat adanya perubahan dari kesulitankesulitan yang dialami pada percobaan pertama, sudah bisa mulai mengatasinya. Hal ini terlihat sesuai hasil pantauan observer telah mencatat keaktifan siswa mencapai $80,59 \%$. Selanjutnya pada percobaan ketiga keaktifan siswa semakin bertambah sehingga observer mencatat keaktifan siswa mencapai $89,71 \%$. Demikian seterusnya hingga percobaan keenam keaktifan siswa mencapai 98,53\%.

Hasil refleksi penelitian bersama guru kolaborator setelah pelaksanaan disimpulkan: (1) kegiatan percobaan II berjalan cukup baik, (2) siswa yang melaksanakan percobaan II sangat antusias (3) LKS yang diberikan guru kepada siswa mampu menuntun siswa dalam bereksperimen dan mengenferensi hasil percobaan I yang ditemukan (4) persiapan alat dan bahan yang disediakan oleh guru sangat inovatif (5) nilai rata-rata siswa 
mencapai 81,4 dari 25 siswa yang mengikuti pembelajaran.

Berdasarkan hasil refleksi percobaan II sudah baik dengan adanya

\section{PEMBAHASAN}

Analisis retrospektip diuraikan berdasarkan data yang terkumpul dari percobaan rintisan dan percobaan pengajaran. Sebagaimana yang telah dijelaskan sebelumnya, tujuan dari pelaksanaan penelitian ini adalah menerapkan permainan sut-sut dengan pendekatan pendidikan matematika realistik Indonesia untuk pembelajaran bilangan pada siswa kelas III sekolah dasar. Dengan tujuan ini, untuk mengetahui desain pembelajaran bilangan melalui permainan sut-sut menggunakan pendekatan PMRI dapat digunakan siswa untuk memperoleh pengetahuan awal bilangan dan konsep dasar bilangan di kelas III sekolah dasar. Selain itu, tujuan yang kedua dari penelitian ini adalah menghasilkan desain pembelajaran bilangan melalui permainan sut-sut menggunakan pendekatan PMRI dapat mengembangkan pemahaman bilangan siswa tentang konsep bilangan melalui aktivitas informal ke formal di kelas III sekolah dasar. Selain itu, tujuan yang ketiga dari penelitian ini adalah Untuk mengetahui desain pembelajaran bilangan melalui permainan sut-sut menggunakan pendekatan PMRI dapat meningkatkan hasil belajar siswa di kelas III sekolah dasar. Hal ini dapat dicapai dengan mengikuti perkembangan pemahaman bilangan siswa tentang konsep bilangan melalui aktivitas informal keformal dikelas III sekolah dasar melalui penggunaan bermain sut-sut sebagai titik awal aktivitas.

Desain pemodelan yang muncul dapat mendukung perkembangan siswa mulai dari situasi nyata menuju penalaran formal. Mengacu pada karakteristik kedua pendidikan matematika realistik, penggunaan model dan simbol alat peraga yang dimunculkan dalam proses pembelajaran.

matematisasi progresif dengan menekankan pada bagaimana suatu model dan simbol digunakan sebagai penghubung dari tingkat nyata menuju tingkat yang lebih formal.

Bermain sut-sut sebagai basis aktivitas yang dilakukan pada tingkat situasional menjadi awal siswa untuk membangun konsep bilangan. Konservasi bilangan sehingga siswa dapat mengenal komponen bilangan seperti bilangan acuan dan bilangan. Pengembangan konsep bilangan yang dimiliki siswa melalui masalah model-of dari bermain sut-sut mendorong mereka untuk mengembangkan kemampuan membilang. Bukan hanya menggunakan konsep penjumlahan, tetapi perkalian dan pengurangan menjadi bagian dari strategi siswa untuk membilang. Bahkan, mengkombinasikan konsep penjumlahan dan pengurangan atau konsep perkalian dan pengurangan merupakan perkembangan pemahaman bilangan yang menarik dari siswa.

Penelitian desain merupakan penelitian kolaborasi antara penelitian dan guru. Kegiatan ini juga membutuhkan syarat perlu adanya aspek yang mendukung pelaksanaan penelitian, misalnya rencana lintasan belajar, dan teori instruksi lokal. Karena itu dibutuhkan penyesuaian dimana apa yang dipahami oleh peneliti harus cocok dengan yang dipahami oleh guru sedemikian sehhingga saat faktor guru tidak menjadi penyebab adanya bias sistematik dan tidak sistematik dalam penelitian.

Pentingnya penyesuaian tersebut mendorong peneliti yang juga sebagai desainer perlu melatih guru sebelum kegiatan lapangan dilakukan. Kegiatan ini 
biasa dilakukan ketika peneliti dan guru membahas rencana lintasan belajar dan aktivitas yang akan dilakukan. Selain itu, peran pengamat juga ditunjukkan dalam bentuk mengamati kegiatan dan proses pembelajaran yang terjadi dengan tujuan mengumpulkan data dan informasi penelitian. Biasanya, ada kesempatan dimana guru model tidak sempat memberikan penjelasan kepada siswanya yang dimanfaatkan peneliti untuk mengeksplorasi pemahaman bilangan siswa. Kesempatan ini menjadi berharga bagi peneliti sebagai guru kepada siswa yang membutuhkan penjelasan lebih lanjut mengenai aktivitas yang sedang mereka lakukan.

\section{KESIMPULAN DAN SARAN}

Berdasarkan Hasil dan Pembahasan, dikaitkan dengan tujuan penelitian ini dapat diajukan kesimpulan sebagai berikut: (1) Untuk mengetahui permainan sut-sut dalam pembelajaran bilangan pada siswa kelas III sekolah dasar ditunjukkan dengan: (a) pengunaan sut dan rumah sebagai objek konservasi bilangan, (b) pemerolehan konsep dasar bilangan, dan (c) pengembangan bentuk bilangan berbasis rumah. Keterpaduan antara permainan ini dengan pendekatan PMRI dapat dilihat dari: (a) bermain sut-sut sebagai aktivitas berbasis pengalaman untuk pembelajaran bilangan; (b) diskusi kelas yang mengacu pada topik bermain sut-sut dengan menitikberatkan peran guru dan interaksi sosial siswa, (c) pemodelan yang muncul mendukung matematisasi progresip dengan berbasis bermain sut-sut, (d) organisasi kelas sebagai komponen didaktik yang mendukung terlaksanaan pembelajaran matematika siswa; dan (e) keterkaitan topik (bermain sut-sut dan membilang
Penggunaan desain pembelajaran bilangan melalui permainan sut-sut menggunakan PMRI dikelas III sekolah dasar mengantarkan siswa semakin baik hasil belajarnya karena mudah, tidak menyulitkan, dan menyenangkan dalam permainan. Sehingga mereka dapat merespon materi pembelajaran bilangan dengan baik dan dapat memenuhi tujuan pembelajaran.

Jadi peningkatan nilai anak juga sangat dipengaruhi banyaknya tindakan perbaikan yang dilakukan oleh guru, semakin banyak tindakan perbaikan oleh guru pada kegiatan mengajar maupun kegiatan siswa sehingga dapat meningkatkan hasil belajar siswa

kotak buku) yang diberikan dapat mengembangkan pengetahuan siswa tentang matematika. (2) Untuk menghasilkan desain pembelajaran bilangan melalui permainan sut-sut menggunakan pendekatan PMRI dapat mengembangkan pemahaman bilangan, melalui aktivitas bermain sut-sut konsep dasar dibangun dengan ide konservasi "berapa banyak kemenangan (yang diperoleh)" dan "berapa banyak kemenangan yang dibutuhkan". Hal itu ditunjukkan untuk menyelesaikan masalah pada setiap aktivitas yang diberikan dimana siswa mencirikan penyelesaian masalah dengan konsep yang digunakannya. Seperti penggunaan konsep penjumlahan dan perkalian dalam membilang percobaan pengajaran I dan juga melibatkan penggunaan konsep penggurangan pada percobaan II. (3) Untuk mengetahui desain pembelajaran bilangan melalui permainan sut-sut menggunakan pendekatan PMRI dapat meningkatkan hasil belajar siswa di kelas 
III sekolah dasar dikarenakan mudah, tidak menyulitkan, menyenangkan dalam permainan sut-sut dan tidak membosankan peserta didik, sehingga mereka dapat merespon materi pembelajaran sesuai dengan tujuan pembelajaran yang diharapkan. Dapat dilihat dari data yang diperoleh menunjukkan ada peningkatan hasil belajar dari uji tes pertama dengan uji tes kedua. Dimana pelaksanaan uji tes pertama pada siswa kelas III/A MI ICI menunjukkan hasil tes dimana siswa yang tuntas dari KKM sebanyak 21 siswa (84\%) dari 7 siswa dengan nilai tertinggi: 100 dan nilai terendah sebanyak 4 siswa $(16 \%)$ dengan nilai rata-rata 81,4. Sedangkan data pelaksanaan uji tes pada siswa kelas III/A SDN 21 kendari barat menunjukkan hasil belajar siswa dengan desain pembelajaran bilangan melalui permainan sut-sut mengalami peningkatan dari uji tes pertama. Dilihat dari hasil tes diketahui bahwa siswa yang tuntas dari KKM sebanyak 24 siswa $(88,89 \%)$ dimana 12 siswa dengan nilai tertinggi: 100 dan nilai terendah sebanyak 3 siswa $(11,11 \%)$ dengan nilai rata-rata 87,78 .

Berdasarkan hasil penelitian dan kesimpulan di atas, maka dapat disarankan sebagai berikut:

1. Perlunya penggunaan konteks (misalnya permainan sut-sut) sebagai situasi dalam kegiatan pembelajaran matematika yang berbasis pengalaman (terutama aspek bilangan) untuk membantu siswa dalam pemerolehan pengetahuan awal dan konsep dasar bilangan.

\section{DAFTAR PUSTAKA}

Freudenthal, H. 1973. Mathematics asaneducational task. Dordrecht,
2. Perlunya penerapan pendekatan PMRI dalam kegiatan pembelajaran matematika untuk mendukung langkah praktis yang membantu siswa dapat mengembangkan pemahaman bilangannya.

3. Untuk mendukung keterlaksanaan pembelajaran matematika yang berbasis pengalaman, (realistik), utamanya bagi peneliti yang akan melaksanakan penelitian desain,. Perlunya guru yang memahami karakteristik dan prinsip PMRI sebaga guru model untuk memperoleh hasil dan mencapai tujuan yang diharapkan.

4. Untuk meningkatkan profesionalisme guru, pelatihan desain pembelajaran bagi guru sekolah dasar merupakan kegiatan yang tepat dimana mereka akan dilatih untuk merancang aktivitas dan perangkat pembelajaran dalam mendukung proses pembelajaran matematika yang bermakna dan menyenangkan.

5. Bagi peneliti (penelitian desain pembelajaran), perlunya kesiapan memberikan pelatihan kepada guru yang dilibatkan dalam kegiatan penelitian terutama saat mendiskusikan rencana lintasan belajar dan teori instruksi lokal. Selain itu, peran pengamat dan guru bagi peneliti dibutuhkan untuk mendukung guru model selama kegiatan pembelajaran dilakukan dan keterlaksanaan kegiatan penelitian.

the Netherlands: Kluwer Academic Publishers. 
Freudenthal, H. 1991. Revisiting Mathematics Education:

Chinalectures. Dordrecht, the Netherlands: Kluwer Academic Publishers.

Gravemeijer, K., \& Eerde, Dollyvan. 2009. Design Research asa Means for Building a Knowledge Base for Teachers and Teaching in Mathematics Education. The Elementary School Journal, 109(5).

National Council of Gurus of Mathematics 2000. Principles and Standards for School Mathematics. Reston,VA: National Council of Gurus of Mathematics.

Simonson, M. 2006. Design Based Research, Applications for Distance Education. The Quarterly Review of Distance Education, 7(1):vii-viii.

Streefland, L., 1991. Fractions in Realistic Mathematics Education. A Paradigm of Developmental Research. Dordrecht: Kluwer Academic Publishers. 